\title{
Fostering Student's Critical Thinking through a Virtual Reality Laboratory
}

\author{
https://doi.org/10.3991/ijim.v14i08.13069
}

\author{
Jaslin Ikhsan $\left.{ }^{\varpi}\right)$, Kristian Handoyo Sugiyarto, Tiwi Nur Astuti \\ Universitas Negeri Yogyakarta, Yogyakarta Indonesia \\ jikhsan@uny.ac.id
}

\begin{abstract}
Virtual reality (VR) laboratory is great potential for education. It is recognized as a technological advance that can facilitate a learning process through the development of highly realistic 3D visualization. Using VR laboratory in teaching and learning makes it possible to manipulate objects in the virtual scene in a manner similar to the real world. Virtual reality laboratory was developed to enhance the students' critical thinking skills. A Research and Development $(\mathrm{R} \& \mathrm{D})$ method with a post-test design was used in the research. The subjects included the students who were enrolled at Senior High School in Yogyakarta, Indonesia with a total of 96 grade 10th students. The samples divided into three classes, namely EC-1 with virtual reality laboratory, EC-2 with virtual reality and real laboratory, and $\mathrm{CC}$ with real laboratory while the quality VR was applied to chemistry teachers. The findings of this research reveal that the quality of VR laboratory integrated hybrid learning was in a very good category. The results of students' critical thinking skills were analyzed using ANOVA test and it was found that there is a significant difference on students' critical thinking skills of the three classes. Students who took part in learning using VR laboratory both in the EC-1 and EC-2 classes had better critical thinking skills compared to the CC class. Thus, the VR laboratory is potentially used for further teaching-learning process.
\end{abstract}

Keywords - Virtual reality, 3D visualization, hybrid learning, critical thinking skills, laboratory.

\section{Introduction}

Computer programming is crucial in today's era and we are living in the place where computer programs are found everywhere [1]; [2]. Technological advances that are developing very rapidly make people rely on smartphone apps to manage their daily routines which fuelled by computer programming. Currently, virtual reality (VR) with 3D visualization has great potential for education. VR technologies have been applied in science and chemistry [3]; [4]. VR technology can improve students' academic performance [4]. It allows immersing a user in a 3D, interactive, provide students with visual, experiential, and self-directed learning [5]; [6]. Using in teaching and learning makes it possible to conjure visualisations that cannot be achieved using 
a traditional method. The simulations of virtual reality were developed and appropriately placed in the teaching materials to enhance the student understanding of complex concepts and learn [7]; [8].

Simulations in virtual reality are interactive digital teaching and learning that imitate a real life. Simulations using virtual reality are also helpful because students can practice their skills that otherwise could be dangerous to practice in real condition [4]. Students who played simulations in virtual reality and then engaged in discussions that drew analogies between the simulations and concepts they were taught would learn more than students who did not play the simulations. The immersive VR may not be an optimal medium for learning basic concepts and facts, but could have greater potential in helping students develop their imagination through $3 \mathrm{D}$ interactions once the students have a basic understanding of the material [9]. In virtual worlds, students can be simultaneously provided with $3 \mathrm{D}$ visualization and learn to operate the virtual worlds via virtual reality laboratories. So, they can practice meaningful experiments and collect data.

The development of ICT has introduced a blender and a unity program that has not been used optimally as chemistry learning media. The program can be used to develop virtual reality with $3 \mathrm{D}$ visualization that can be operated with Android. The development of virtual reality is very promising for future technology that can be developed as a medium for virtual experiments. Using instructional media can make learning more interesting and motivating, more interactive, easier to understand subject matter, learning methods become more varied, learners become more active, and learning processes can take place anytime and anywhere [10]; [11]; [12]. Using 3D visualization in this research is also expected to be an alternative solution for schools that do not have laboratory facilities, both in the form of chemicals and other practical equipment.

The 3D visualization allows people to see things that cannot be seen in the real world and observe things from the real world in ways impossible in the real world [13]; [14]; [15]. By providing spatial information in visualization, it can make big steps to unite visual effects and information acquisition. A chemist needs visualization for the progress of the knowledge, especially in relation to complex chemical molecules. In chemistry, 3D visualization is very important for understanding spatial relations between atoms [16].

The popularity of the information technology has grown rapidly, especially elearning. One of the developments of e-learning is hybrid learning that can present online course material in interactive and stimulating ways for students and creating an online learning community. Hybrid learning can use the Learning Management Systems (LMS) for example edmodo that allowing them to manage the distribution of assignments, quiz, and course material. The importance of e-learning has been highlighted previously and as a result online forum can be used as a place for interactive discussions [17]; [18]; [19]. Hybrid learning is being combined with independent online study and traditional classroom method [20]. Hybrid learning allow students to communicate with their peers and teachers thus empowering them to learn and discuss together online. 
Online learning is one of the important communication and there are some systems that can be used such as e-mail, discussion boards, instant messages, and online forums [19]; [21]. Hybrid learning consists of synchronous and asynchronous technologies. Synchronous technologies can bring a real-time element into communicating online and enhance a learning experience [22]; [7]. Asynchronous technology is a good collaboration involving an interaction between teachers and students, although students cannot receive instant feedback [23].

Through the use of virtual reality (VR) with hybrid learning, students can be more visually aware of their classmates and converse in real-time with them [21]. They would receive feedback from teachers and allow them to actively involved in group discussions at the same time. VR is developed with $3 \mathrm{D}$ visualization with features of different shapes, objects, and animation. It makes learning more fun and can be used to teach students with different procedures for carrying out assignment [24]. Hybrid learning also brings a great deal to an e-learning experience, communicating online, and on providing adequate support for a variety of learning assignments.

The $21^{\text {st }}$ century skills suggest a temporary core skill known as $4 \mathrm{C}$ which include critical thinking and problem solving, communication, collaboration, creativity and innovation [25]. Critical thinking skills are one of the skills that need to be developed in the current era. These skills include the skills of analyzing, evaluating, and synthesizing. Critical thinking skills can be defined as a person's ability to test their idea in dealing with problems the art of analysis and evaluating thinking, deducting and inferring conclusions from problems and facts [26]; [27]. In this research, we developed a virtual reality laboratory designed to train students' critical thinking skills so that they are accustomed to thinking deeply in solving problems encountered.

The main issues from the literature show that virtual reality can enhance students' critical thinking skills. We developed a virtual reality laboratory integrated hybrid learning to achieve research goals of improving students' critical thinking skills through the VR. Thus, the following research questions for this research:

1. How are the characteristics of virtual reality laboratory on chemistry?

2. How is the quality of virtual reality laboratory on chemistry?

3. Are there differences in critical thinking skills among students who use virtual reality laboratory integrated hybrid learning both as supplements and subtitutes with students who carry out practical learning in a real laboratory?

\section{Method}

This research used Research and Development (R\&D) method - ADDIE model, including: analysis, design, develop, implement, and evaluate [28]. The development product was a virtual reality laboratory in a chemical bonding practicum course. The assessment of the effects of a virtual reality laboratory was conducted based on a posttest design where there were two experimental classes (EC-1 \& EC-2) and one control class (CC). A total of 96 participants were recruited from three classes of $10^{\text {th }}$ grade students of a senior high school. One class with a total of 32 students were cluster randomly selected as the experiment class-1; the second class with a total of 32 stu- 
dents were assigned as the experiment class-2; while the third class with a total of 32 students were assigned as the control class.

The independent variable in this research was instructional media. The EC-1 used a virtual reality laboratory integrated hybrid learning, EC-2 used real laboratory and virtual reality laboratory integrated hybrid learning, while CC used real laboratory. The dependent variable was critical thinking skills and the posttest was obtained for measures. Chemical bonding tests were conducted to obtain data on students' critical thinking skills. It consists of 6 items of short essay questions. The posttest included the critical thinking skills. These measures had Cronbach's alpha reliabilities of 0.82 .

\subsection{Research design}

The procedure of the research in this development refers to the ADDIE development model which can be explained as follows. The first step was initial needs analysis which included collecting information by observing learning activities directly in school and also through interviews with senior high school teachers. The purpose of this stage is to obtain various information regarding the availability of infrastructure, learning media, implementing learning, reviewing the curriculum to form indicators of achievement of competencies, and potential that can be developed from learning in schools. Besides, a literature study was also conducted by reviewing various existing literature such as journals, research reports, and other sources. The initial needs analysis is done by formulating a general description of the $3 \mathrm{D}$ visualization learning media that will be developed to suit the characteristics of the students. Based on the results of the analysis, a new approach is being developed in the making of 3D visualization objects by utilizing technological developments, such as augmented reality and virtual reality [29]; [30]. In Indonesia, the use of 3D visualization media based on virtual reality is still rare.

The second step was product design carried out by collecting various references as supporting components in the making of a virtual reality laboratory in the form of materials, animations, videos, images, color compositions, tools and materials as well as procedures for experimental simulation. Practicum designed in this VR was chemical bonding course. The third step was a development of VR products. Virtual reality laboratory products were developed using a blender and unity on computer programs. The blender program serves to build 3D visualization objects, animations in simulations, and compose textures from 3D object components. After all 3D objects are created, then combine all the objects and make the object interaction using the unity program. After all 3D visualization objects are filled into one unit on a computer, virtual reality laboratory product can be used using smartphones (Android).

The next step was an implementation by testing virtual reality laboratory products. Tests were conducted with the experimental class (EC-1 and EC-2) and the control class (CC) to test the effectiveness of the product developed through the students' critical thinking skills. The last step was product evaluation by evaluating VR product quality to senior high school teachers. The product implementation phase uses the quasi-experimental method with posttest design which can be seen in Table 1. 
Table 1. Posttest design

\begin{tabular}{|l|l|l|}
\hline \multicolumn{1}{|c|}{ Classes } & \multicolumn{1}{c|}{ Treatment } & \multicolumn{1}{c|}{ Post-test } \\
\hline Control Class (CC) & $\mathrm{X} 1$ & $\mathrm{P} 1$ \\
\hline Experiment Class -1 (EC-1) & $\mathrm{X} 2$ & $\mathrm{P} 1$ \\
\hline Experiment Class -2 (EC-2) & $\mathrm{X} 3$ & $\mathrm{P} 1$ \\
\hline
\end{tabular}

Note: $\mathrm{X} 1$ = learning with real laboratory, $\mathrm{X} 2$ = hybrid learning mediated by virtual reality, $\mathrm{X} 3=$ learning with real laboratory and hybrid learning mediated by virtual reality $\mathrm{P} 1=$ chemical bonding test

\subsection{Data analysis}

Analysis of Variance (ANOVA) technique and qualitative descriptive were used to analyze students' critical thinking skills. Quality of virtual reality laboratory was analyzed by quantitative descriptive method. Thus, the data were classified into a category based on the ideal rating category. The rating category can be seen in Table 2 .

Table 2. Ideal rating category

\begin{tabular}{|c|l|}
\hline Score & \multicolumn{1}{|c|}{ Range Quality } \\
\hline$\underline{X}>\underline{X_{i}}+1.8 \mathrm{SBi}$ & Very Good \\
\hline$\underline{X_{i}}+0.6 \mathrm{SBi}<\underline{X} \leq \underline{X_{i}}+1.8 \mathrm{SBi}$ & Good \\
\hline$\underline{X_{i}}-0.6 \mathrm{SBi}<\underline{X} \leq \underline{X_{i}}+0.6 \mathrm{SBi}$ & Good Enough \\
\hline$\underline{X_{i}}-1.8 \mathrm{SBi}<\underline{X} \leq \underline{X_{i}}-0.6 \mathrm{SBi}$ & Poor \\
\hline$\underline{X} \leq \underline{X_{i}}-1.8 \mathrm{SBi}$ & Very Poor \\
\hline
\end{tabular}

Note: $X$ is the empirical score; $X_{i}$ is the average of ideal scores; $\mathrm{SBi}$ is the ideal score of standard deviation

\section{Results}

\subsection{Developing process}

The ability of providing highly interactive learning experiences was one of the best-valued features of virtual reality. We decided to use Blender and Unity on computer programs which have good support to build 3D objects. Blender is a program for modeling, animation and rigging and Unity is for implementation [31]. Blender was chosen as the primary tool for all 3D modeling and animation. It can be used for modeling 3D objects, rendering, rigging, UV mapping, sculpting, animation, etc. The $3 \mathrm{D}$ objects created in this program include: laboratory room, cupboard, tables, clamp, burets, beakers, magnets, funnels, and other laboratory equipment. The 3D objects that have been created are then rendered so that the object's appearance becomes clear and appropriate. The 3D model being built in Blender can be seen in Figure 1. 


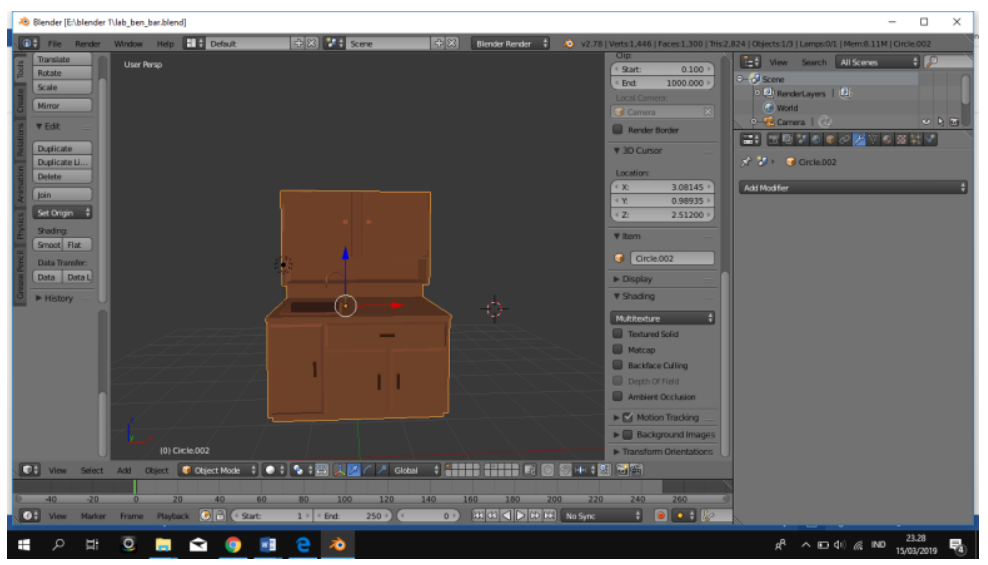

Fig. 1. The 3D Model being built in Blender

Furthermore, all 3D objects integrated into Unity programs. Unity is best suited for small or middle-sized development studios and combines visual simulation capabilities with interactive functions and ease of use in the context of geometry data input and output [31]; [32]. The 3D objects which has been incorporated into the Unity program can be seen in Figure 2.

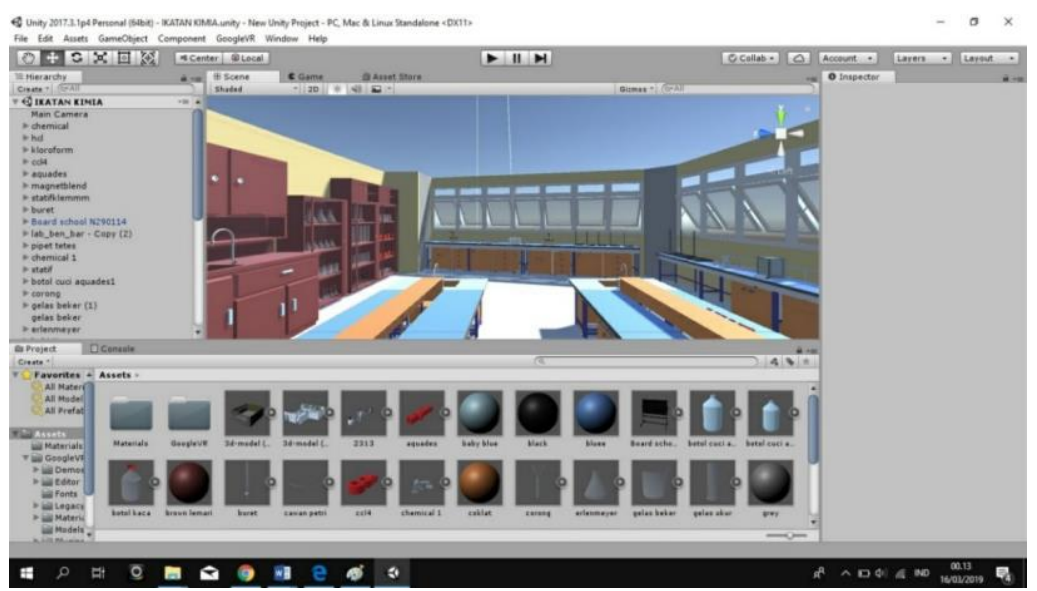

Fig. 2. Virtual reality laboratory in Unity

This virtual reality laboratory can only be operated using Android. However, we can monitor via computer using the "Team Viewer" program. VR displays on computers can be seen in Figure 3. 


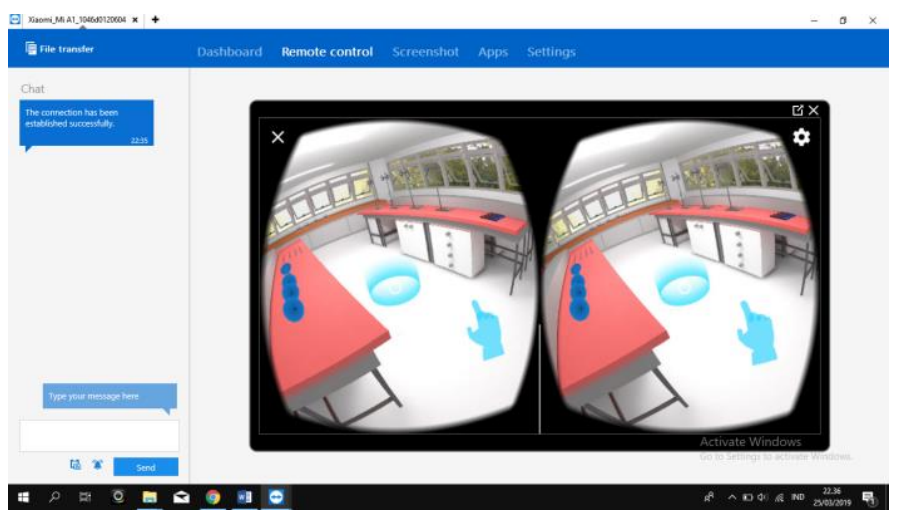

Fig. 3. VR display on a computer through the "Team Viewer" program

Virtual reality can be operated using an Android equipped with 3D glasses and a controller. The simulation allows students to virtually work through polarity compounds in a lab. It starts by introducing the students to the virtual laboratory environment. The VR simulation increases motivation by having students experience the excitement of learning, increases critical thinking and conceptual understanding, increases scientific skills by having students test, explore, predict, observe, and makes sense of relevant material in a virtual environment that simulates real laboratory [33]; [34]; [35].

\subsection{Effect of virtual reality on critical thinking skills}

The implementation of VR laboratory products aims to measure students' critical thinking skills. The results of product implementation are the post-test values of critical thinking skills which can be seen in Table 3 and the summary of ANOVA can be seen in Table 4.

Table 3. Descriptive statistics of critical thinking skill

\begin{tabular}{|l|c|c|c|}
\hline \multicolumn{1}{|c|}{ Classes } & N & Mean & SD \\
\hline Control Class (CC) & 32 & 67.5 & 12.8 \\
\hline Experiment Class -1 (EC-1) & 32 & 79.4 & 11.8 \\
\hline Experiment Class -2 (EC-2) & 32 & 77.5 & 9.8 \\
\hline
\end{tabular}

Table 4. Summary of ANOVA analysis

\begin{tabular}{|c|c|l|}
\hline F Value & Sig. Value & \multicolumn{1}{c|}{ Conclusion } \\
\hline 9.789 & 0.000 & Significantly different \\
\hline
\end{tabular}

The highest average of critical thinking skills was obtained by experimental class-1 and followed by experimental class-2. Both classes applied learning using an integrated hybrid learning virtual reality laboratory both as a supplement and as a substitute. The combination of virtual laboratories has a positive effect on students' learning 
outcomes in conducting experiments [36]. This is also in accordance with the statement of Higgins et al. (2012) the use of technology in the interaction between educators and students has a good impact on student learning outcomes because learning is more effective.

Based on Table 4, it shows that there is significant influence of virtual reality integrated hybrid learning towards students' critical thinking skills. Practicum using virtual reality makes students more active and enthusiastic in participating in learning, unlike the practices in a real laboratory that makes students saturated and less active because they cannot develop their imagination [36]; [37]. Based on observations during the learning process, class EC-1 and EC- 2 obtained better results because students in both classes had high curiosity, always asked questions in learning, and were active in discussion and presentation activities. This is also supported by the application of hybrid learning in EC-1 and EC-2. The lessons with VR laboratory allow more effective learning experience with significant improvements compared to learning with traditional lessons alone [38].

Implementation of integrated virtual reality hybrid learning laboratory was conducted in 4 meetings. Hybrid learning is carried out with face-to-face and online phases: synchronous and asyncronous. The online phase in the learning process uses various programs in the computer, including skype, instant messaging (IM), e-mail, and online discussion forums. The online phase in hybrid learning provides additional learning time to students, can add a reference to learning resources, influences learning outcomes, and encourages an interaction among students [39]; [40]. Hybrid learning makes students capable of working together in groups and solving problems together well. With the data obtained through discussion and practicum activities they would try to combine the data they obtained both from practicum and discussion with data obtained from other sources during hybrid learning. Thus, they will be trained to think critically in solving problems.

The quality of VR applied to 8 senior high school teachers consists three aspects, namely content, learning and technical quality. These three aspects were described into 22 indicators. The quality of VR for each aspect can be seen in Table 5 .

Table 5. The quality of VR

\begin{tabular}{|l|c|c|l|}
\hline \multicolumn{1}{|c|}{ Aspects } & \multicolumn{2}{c|}{ Average Score } & \multicolumn{1}{c|}{ Category } \\
\hline & Total & Maximum & \\
\hline Content & 30.20 & 32 & Very good \\
\hline Learning & 29.44 & 32 & Very good \\
\hline Technical & 30.13 & 32 & Very good \\
\hline
\end{tabular}

Based on Table 5, the quality of VR laboratory integrated hybrid learning is in a very good category. Teachers considered that the VR was assumed to be easy to understand, motivated students to help their learning process, and the display of VR was clear like real laboratory. Teachers stated that the presence of a virtual reality laboratory would make students more enthusiastic in attending classes. This is supported by the development of the digital era where students are more flexible in practicing virtually with clear 3D objects and interaction in media that is fun and easy to operate. 
The virtual chemistry laboratory has been successfully developed as experimental media, improvement of students' creativity, has instructional characteristics with a positive contribution to education, improves students' achievement and the quality of the virtual chemistry laboratory integrating hybrid learning is in a good category [41]; [42]; [43].

\section{$4 \quad$ Limitations and Suggestions for Future Work}

Although the study provides positive results, there are still some limitations in this study. First, this virtual reality laboratory product can only be operated using Android. Second, practicum material in this media only contains one subject, so it is necessary to develop VR laboratory media on another subject. Thirdly, this media does not yet have audio due to limitations on $3 \mathrm{D}$ glasses that are not yet equipped with headphones.

Suggestions for the use of virtual reality laboratory products based on the results of research and development that has been done is that the virtual reality laboratory media can be further developed with different material and can be used as action research. Furthermore, further research is needed to measure the effectiveness of the use of $3 \mathrm{D}$ visualization media in virtual reality on a broader scale. In addition, it is necessary to develop more virtual reality laboratory media with the addition of more complex, interactive $3 \mathrm{D}$ objects. It is necessary to add audio and learning games in this media.

\section{Conclusion}

Based on the results of research and development of integrated hybrid virtual reality laboratories, the conclusions are that the characteristic of virtual reality laboratory is that this media can be operated using android with the help of 3D glasses and a controller. This simulation in $3 \mathrm{D}$ visualization is a compound polarity practicum on chemical bond material in a virtual environment so it is as if the user is doing a practicum in the real world. The quality of virtual reality laboratories in chemical bonding material is a very good quality in terms of learning, content, and techniques based on the assessment from the chemistry teachers. There are significant differences in critical thinking skills between students who use virtual reality laboratory integrated hybrid learning both as supplements and substitutes with students who carry out practicum learning in a real laboratory.

\section{Conflict of Interests}

The authors declare there no conflict of interest. 


\section{$7 \quad$ Acknowledgement}

Authors would like to thank the Directorate General of Higher Education, Ministry of Research, Technology and Higher Education, The Republic of Indonesia for funding this research.

\section{$8 \quad$ References}

[1] Lye, S. Y., \& Koh, J. H. L. (2014). Review on teaching and learning of computational thinking through programming: What is next for K-12? Computers in Human Behavior, 41, 51-61. https://doi.org/10.1016/i.chb.2014.09.012

[2] Ismail, S. S., \& Abdulla, S.A. (2019). Virtual flipped classroom: new teaching model to grant the learners knowledge and motivation. Journal of Technology and Science Education, 9(2), 168-183. https://doi.org/10.3926/jotse.478

[3] Kartiko, I., Kavakli, M., \& Cheng, K. (2010). Learning science in a virtual reality application: The impacts of animated-virtual actors' visual complexity. Computers \& Education, 55(2), 881-891. https://doi.org/10.1016/j.compedu.2010.03.019

[4] Merchant, Z., Goetz, E. T., Cifuentes, L., Keeney-Kennicutt, W., \& Davis, T. J. (2014). Effectiveness of virtual reality-based instruction on students' learning outcomes in K-12 and higher education: A meta-analysis. Computers \& Education, 70, $29-40$. https://doi.org/10.1016/j.compedu.2013.07.033

[5] Chittaro, L., \& Ranon, R. (2007). Web3D technologies in learning, education and training: Motivations, issues, opportunities. Computers \& Education, 49(1), 3-18. https://doi.org/10. 1016/j.compedu.2005.06.002

[6] Sun, H.-M., \& Cheng, W.-L. (2009). The input-interface of Webcam applied in 3D virtual reality systems, Computers \& Education, 53(4), 1231-1240. https://doi.org/10.1016/ j.compedu.2009.06.006

[7] Ong, S. K., \& Mannan, M. A. (2004). Virtual reality simulations and animations in a webbased interactive manufacturing engineering module. Computers \& Education, 43(4), 361 382. https://doi.org/10.1016/j.compedu.2003.12.001

[8] Young, M. F., \& Slota, S. T. (2017). Exploding the Castle: Rethinking how video games and game mechanics can shape the future of education. Charlotte, NC: Information Age, Inc.

[9] Meyer, O., Omdahl, M., \& Makransky, G. (2019). Investigating the effect of pre-training when learning through immersive virtual reality and video: A media and methods experiment. Computers \& Education, 140(6), 1-17. https://doi.org/10.1016/j.compedu.2019. $\underline{103603}$

[10] Anwariningsih, S. H., \& Ernawati, S. (2013). Development of interactive media for ICT learning at elementary school based on student self-learning. Journal of Education and Learning (EduLearn), 7(2), 121-128. Retrieved from https://doi.org/10.11591/edulearn. v7i2.226

[11] Tsovaltzi, D., Rummel, N., McLaren, B. M., Pinkwart, N., Scheuer, O., Harrer, A., \& Braun, I. (2010). Extending a virtual chemistry laboratory with a collaboration script to promote conceptual learning. International Journal Technology Enhanced Learning, 2(1/2), 91-110. https://doi.org/10.1504/ijtel.2010.031262 
[12] Högström, P., Ottander, C., \& Benckert, S. (2010). Lab work and learning in secondary school chemistry: The importance of teacher and student interaction. Research Science Education, 40(4), 505-523. https://doi.org/10.1007/s11165-009-9131-3

[13] Wu, H. \& He, Z., \& Gong, J. (2010). A virtual globe-based 3D visualization and interactive framework for public participation in urban planning processes. Computers, Environment, and Urban Systems, 34(4), 291-298. https://doi.org/10.1016/j.compenvurbsys.2009. 12.001

[14] Korakakis, G., Boundouvis, A., Palyvos, J., Pavlatou, E. A. (2012). The impact of 3D visualization types in instructional multimedia applications for teaching science. Procedia Social and Behavioral Sciences, 31, 145-149. https://doi.org/10.1016/j.sbspro.2011.12.032

[15] Satish, C. J., \& Mahendran, A. (2017). The effect of 3D visualization on mainframe application maintenance: A controlled experiment. Journal of King Saud University - Computer and Information Sciences. https://doi.org/10.1016/j.jksuci.2017.03.003

[16] Bowen, J. P., Bowen, A. M., \& Harrison, K. (2016). Creative visualization in chemistry. International Journal Creative Computing, 1(2/3/4), 231-273. https://doi.org/10.1504/ ijcrc.2016.076058

[17] Preece, J. (2000). Online communities: designing usability, supporting sociability. Chichester, UK: John Wiley \& Sons. https://doi.org/10.1108/imds.2000.100.9.459.3

[18] Salmon, G. (2002). E-activities: the key to active online learning. London: Kogan Page.

[19] Thurmond, V. A., \& Wambach, K. (2004). Understanding interactions in distance education: a review of the literature. Journal of Instructional Technology and Distance Learning, 1(1), 9-33. Retrieved from http://www.itdl.org/journal/Jan_04/article02.htm

[20] Bhowmik, J., Meyer, D., \& Phillips, B. (2019). Using blended learning in postgraduate applied statistics programs. Turkish Online Journal of Distance Education, 20(2), 64-77. https://doi.org/10.17718/tojde.557739

[21] Monahan, T., McArdle, G., \& Bertolotto, M. (2008). Virtual reality for collaborative elearning. Computers \& Education, 50(4), 1339-1353.https://doi.org/10.1016/j. compedu.2006.12.008

[22] McInnerney, J. M., \& Roberts, T. S. (2004). Online learning: social interaction and the creation of a sense of community. Educational Technology \& Society, 7(3), 73-81. Retrieved from https://www.jstor.org/stable/jeductechsoci.7.3.73

[23] Diaz, L. A. \& Entonado, F. B. (2009). Are the functions of teachers in e-learning and faceto-face learning environments really different? Educational Technology \& Society, 12(4), 331-343. Retrieved from https://www.j-ets.net/ETS/journals/12_4/28.pdf

[24] Nijholt, A. (2000). Agent-supported cooperative learning environments. In Proceedings of the international workshop on advanced learning technologies. https://doi.org/10.1109/ iwalt.2000.890554

[25] Roekel, D. V (2012). Preparing 21st century students for a global society, an educator guide to the "Four Cs". USA: National Education Association.

[26] Paul, R., \& Elder, L. (2006). The miniature guide to critical thinking concepts and tool. Foundation for Critical Thinking Press. Retrieved from http://www.criticalthinking.org/ files/Concepts_Tools.pdf

[27] Willingham, D. T. (2008). Critical thinking: why is it so hard to teach? Arts Education Policy Review, 109(4), 21-32. https://doi.org/10.3200/aepr.109.4.21-32

[28] Branch, R. M. (2009). Instructional design: The ADDIE approach. USA: Springer.

[29] Domhan, Tobias. (2010). Augmented Reality on Android Smartphone. Jerman: Dualen Hochschule Baden-Wüttemberg.

[30] Bakar, N., Zaman, H. B., Kamalrudin, M., Jusoff, K., \& Khamis. N. (2013). An effective virtual laboratory approach for chemistry. Australian Journal of Basic and Applied Scienc- 
es, 7(3), 78-84. Retrieved from http://www.ajbasweb.com/old/ajbas/2013/special\%20issue 178-84.pdf

[31] Gupta, R., Nawani, R., \& Talreja, V. P. (2016). Virtual reality content creation using unity 3D and blender. International Journal of Computer Applications, 156(3), 8-12. https://doi.org/10.5120/ijca2016912395

[32] Indraprastha, A., \& Shinozaki, M. (2009). The investigation on using Unity3D game engine in urban design study. Journal of ICT Research and Applications, 3(1), 1-18. Retrieved from http://journals.itb.ac.id/index.php/jictra/article/download/180/174 https://doi.org/10.5614/itbj.ict.2009.3.1.1

[33] Limniou, M., Roberts, D., \& Papadopoulos, N. (2008). Full immersive virtual environment CAVETM in chemistry education. Computer \& Education, 51(2), 584593.https://doi.org/10.1016/j.compedu.2007.06.014

[34] Sural, I. (2018). Augmented reality experience: Initial perceptions of higher education students. International Journal of Instruction, 11(4), 565-576. https://doi.org/10. $\underline{12973 / i j i .2018 .11435 \mathrm{a}}$

[35] Makransky, G., \& Petersen, G. B. (2019). Investigating the process of learning with desktop virtual reality: A structural equation modeling approach, Computers \& Education, 134(6), 15-30. https://doi.org/10.1016/j.compedu.2019.02.002

[36] Omilani, N. A., Ochanya, N. M. R., \& Aminu, S. A. (2016). The effect of combined virtual and real laboratories on students' achievement in practical chemistry. International Journal of Secondary Education, 4(3), 27-31. https://doi.org/10.11648/j.ijsedu.20160403.11

[37] Kim, P. (2006). Effects of 3D virtual reality of plate tectonics on fifth grade students' achievement and attitude toward science. Interactive Learning Environment, 14(1), 25-34. https://doi.org/10.1080/10494820600697687

[38] Innocenti, E. D., Geronazzo, M., Vescovi, D., Nordahl, R., Serafin, S., Ludovio, L. A., \& Avanzini, F. (2019). Mobile virtual reality for musical genre learning in primary education. Computers \& Education, 139(5), 102-117. https://doi.org/10.1016/j.compedu.2019.04.010

[39] Means, B., Toyama, Y., Murphy, R., \& Baki, M. (2013). The effectiveness of online and blended learning: A meta-analysis of the empirical literature. Teachers College Record, 115(3), 1-47. Retrieved from https://www.tcrecord.org/content.asp?contentid=16882

[40] Nais, M. K., Sugiyarto, K. H., \& Ikhsan, J. (2019). Virtual chemistry laboratory (virtual chem-lab): Potential experimental media in hybrid learning. Journal of Physics: Conference Series, 1156. https://doi.org/10.1088/1742-6596/1156/1/012028

[41] Fitriyani, N., Wiyarsi, A., Ikhsan, J., \& Sugiyarto, K. H., (2018). Fostering of students' self-regulated learning and achievement: a study on hydrocarbon hybrid-learning and android-based-game. Journal of Physics: Conference Series, 1097. https://doi.org/10.1088/ $1742-6596 / 1097 / 1 / 012064$

[42] Sugiyarto, K. H., Ikhsan, J., Lukman, I. R. (2018). The use of an android-based-game in the team assisted individualization to improve students' creativity and cognitive achievement in chemistry. Journal of Physics: Conference Series, 1022. https://doi.org/10.1088/ $\underline{1742-6596 / 1022 / 1 / 012037}$

[43] Wijayanti, R., Sugiyarto, K. H., \& Ikhsan, J. (2019). Effectiveness of using virtual chemistry laboratory integrated hybrid learning to students' learning achievement. Journal of Physics: Conference Series, 1156. https://doi.org/10.1088/1742-6596/1156/1/012031 


\section{Authors}

Jaslin Ikhsan is a lecturer and researcher in Chemistry Department, Faculty of Mathematics and Natural Science, Yogyakarta State University, Indonesia. His interest of researcher are ICT-based media in chemistry learning and surface chemistry. The media that have been developed are mobile based learning media, web-based media, animation-based media, computer-based media, and ICT-based 3-Dimentional media. Email: jikhsan@uny.ac.id

Kristian Handoyo Sugiyarto is a lecturer and researcher in Chemistry Department, Faculty of Mathematics and Natural Science, Yogyakarta State University, Indonesia. His interest of researchare educational media development in chemistry teaching learning and has been uploaded in the playstore in the tittle of chemondro, misconception observed in chemistry textbooks and the users, students, and teachers.

Tiwi Nur Astuti holds M.Pd (Magister of Education) in the Chemistry Education from Universitas Negeri Yogyakarta in 2019. Her interest is an educational media development as learning innovation, quantitative research in education including the implementation of various chemistry teaching method, and teaching-learning in the chemistry classroom.

Article submitted 2020-01-07. Resubmitted 2020-02-06. Final acceptance 2020-02-20. Final version published as submitted by the authors. 